\title{
Disease perception and coping strategies for stress in Polish patients with various mental disorders
}

\author{
Marta Kłak ${ }^{1}$ ABDEF, Wioletta Karina Ozga ${ }^{2}$ CDEF https://orcid.org/0000-0002-7775-0681 \\ ${ }^{1}$ Institute of Health Care, State Higher School of Technology and Economics \\ ${ }^{2}$ Institute of Psychology, The John Paul II Catholic University of Lublin
}

\begin{abstract}
Introduction: Nowadays more and more people struggle with mental problems associated with fast pace of life and overpowering stress. Individuals affected by mental disorders frequently apply ineffective methods of coping with stress, and their attitudes towards the disease in fact strengthen the psychopathological symptoms. The purpose of the present study was to compare disease perception and coping strategies for stress in Polish patients with various types of mental disorders.

Material and Methods: The study involved 123 patients with depressive disorders, anxiety disorders, schizophrenia, alcohol related disorders, subjects detained due to psychoactive substance-induced psychotic disorders and amnestic syndromes, staying at Mental Healthcare Centre. Measurements of the variables were carried out using COPE Inventory and Disease Perception Questionnaire.

Results: The type of mental disorder differentiated the group with respect to the use of strategies aimed at seeking instrumental and emotional support, planning, positive reinterpretation, focus on emotions and substance use. There are significant differences between patients in the approach to illness as a task, weakness and threat.

Conclusions: The results show that the type of mental disorder is important in the context of the strategies used for coping with stress and the patients' approach to their condition.
\end{abstract}

Keywords: coping strategies, disease perception, mental disorders

\section{Streszczenie}

Wstęp: W obecnych czasach coraz większy odsetek społeczeństwa boryka się z problemami psychicznymi wynikającymi z wysokiego tempa życia i wszechogarniającego stresu. Osoby chorujące na zaburzenia psychiczne stosują często nieskuteczne sposoby radzenia sobie ze stresem a ich postawy wobec choroby tylko wzmacniają objawy psychopatologiczne. Celem przeprowadzonych badań było porównanie obrazu własnej choroby oraz strategii radzenia sobie ze stresem pacjentów z różnymi rodzajami zaburzeń psychicznych.

Materiał i Metoda: Badaniami objęto 123 pacjentów z zaburzeniami depresyjnymi, lękowymi, chorujących na schizofrenię, uzależnionych od alkoholu i internowanych z diagnozą zaburzeń psychotycznych i zespołów amnestycznych spowodowanych przyjmowaniem środków psychoaktywnych. Do pomiaru zmiennych zastosowano Wielowymiarowy Inwentarz do Pomiaru Radzenia Sobie ze Stresem - COPE i Kwestionariusz Obrazu Choroby - KOCh.

Wyniki: Rodzaj choroby psychicznej różnicuje grupę w zakresie częstotliwości stosowania strategii ukierunkowanych na poszukiwanie wsparcia instrumentalnego i emocjonalnego, planowanie, pozytywne przewartościowanie, koncentracje na emocjach i zażywanie alkoholu. Odnotowano istotnie różnice pomiędzy badanymi grupami w nasileniu postaw wobec choroby jako zadania, słabości i zagrożenia.

Wnioski: Wyniki wskazują, że rodzaj zaburzenia ma znaczenie w kontekście stosowanych strategii radzenia sobie ze stresem i postawy wobec swojej choroby.

Słowa kluczowe: strategie radzenia sobie ze stresem, obraz własnej choroby, zaburzenia psychiczne 


\section{Introduction}

Today more and more people struggle with mental problems associated with fast pace of life and overpowering stress. Individuals affected by mental disorders frequently apply ineffective methods of coping with stress, and their attitudes towards the disease in fact strengthen the psychopathological symptoms.

In scientific literature there are numerous definitions of disease referring to biological, psychological and social contexts [1,2]. From the viewpoint of the research problem, attention has been paid to the aspect of disease associated with subjectively experienced discomfort and suffering [3]. Perception of one's illness does not only depend on the patient's biological condition but also on the individual's beliefs related to the nature of the disease and his/her attitude to it $[4,5]$. In the present study it was assumed that an attitude means the patients' individual approach to the fact they are affected by an illness and to situations linked with the illness $[3,6]$. The emotional component of the attitude is determined by emotional approach to the disease, knowledge of the disease, its cognitive dimension and the behavioural component of the attitude is determined by behaviours [7]. One's attitude to the illness may change with time. Each component of the attitude evolves depending on whether it is the stage of being shocked, aiming for equilibrium or mastering the condition of being ill [8]. Research has shown that one's attitude results from cognitive assessment of the condition of being ill, and contributes to the quality of life subjectively experienced by those affected by mental disorders [9]. Responses to illness may vary, depending on the meaning attributed to the condition by the patient [10]. Illness may be treated as a threat, benefit, weakness or task $[11,12]$. If illness is treated as a threat, it is seen as a factor imposing restrictions on all dimensions of life. The patient feels helpless, depressed, threatened and anxious. A medical condition is seen as a benefit if, as a result, a patient receives care and attention. The illness becomes a life purpose, and allows to escape problems and responsibilities of daily life. Search for information about causes and symptoms, as well as mobilisation for overcoming the problem are characteristic if an illness is seen as a task. Treating illness as a weakness is associated with a lack of acceptance for the diagnosis, a tendency to trivialise the symptoms, to deny or refuse to admit there is any problem.

Complex and dynamic in nature, the process of coping with stress comprises a totality of activities undertaken by a person in a difficult situation. The passage of time results in the fact that it is possible to distinguish in that process specific activities, varied in terms of quality. These activities are referred to as strategies or methods of coping with stress. On the other hand, a coping style relates to the way a given person typically behaves in stressful conditions. Activities undertaken by a patient in a specific case result from interactions between the characteristics of a stressful situation and his/her personal coping style [13]. The related literature suggests that individuals affected by mental disorders tend to use dysfunctional ways of coping with stress $[5,14,15]$. Important role in employing different ways of coping with emotional difficulties, associated with illness, is played by the activated defence mechanisms $[16,17]$.

Being a source of social stigma, mental disorder is an experience which is difficult to get used to [18]. According to DSM-V: "A mental disorder is a syndrome characterized by clinically significant disturbance in an individual's cognition, emotion regulation, or behaviour that reflects a dysfunction in the psychological, biological, or developmental processes underlying mental functioning" [19]. Additionally, mental disorders lead to suffering, or even disability, affecting one's social life and work [20]. The attitude towards a specific mental disorder as well as strategies applied in stressful situations may be determined by different aetiology and axial symptoms unique for a given condition [21]. The purpose of the study was to compare disease perception and strategies of coping with stress in patients with various types of mental disorders.

\section{Material and method}

The examinations were carried out individually, in Antoni Kępiński Specialist Mental Healthcare Centre in Jarosław, in compliance with the ethical rules defined in the Declaration of Helsinki. The study was approved by the Ethics Committee of Medical University of Lublin (the project identification code: KE-0245/133/2014). All the subjects provided written consent to participate in the study. Differential diagnosis of a mental disorder, according to International Statistical Classification of Diseases and Related Health Problems ICD 10, was applied as a criterion for selecting into the study group. Comparative analyses took into account results achieved by patients with diagnosis of five types of mental disorders: depressive disorders (F32, F33), anxiety disorders (F41, F42, F43), alcohol related disorders (F10), schizophrenia (F20), psychoactive substance induced psychotic disorders and amnestic syndromes - associated with detainment at the psychiatric ward (F19.5, F19.6). Patients detained in psychiatric hospitals include individuals who committed an unlawful act while being non-accountable. Additionally, according to expert psychiatrists, due to the diagnosed mental disorder, there is high likelihood the same act may be committed again $[22,23]$.

The study group comprised 123 patients ( 34 females and 89 males). Those examined included 25 patients 
detained in hospital, diagnosed with psychoactive substance-induced psychotic disorders and amnestic syndromes, 20 subjects with depressive disorders, 27 with schizophrenia, 21 with anxiety disorders, 30 with alcohol related disorders. The subjects had been affected by the mental disorders for a varied length of time, ranging from six months to 39 years, with the mean of $\mathrm{M}=10.68$ (SD = 8.18). The mean number of hospital stays was $M=4.28$ (SD = 4.27), although some of the patients visited psychiatry wards even 30 times. On average the patients were nearly 43 years old $(M=42.82 ; S D=11.24)$, the youngest being 22 and the oldest 71 years old. Most patients had completed vocational education (35.77\%), or secondary schools (32.52\%), with considerably lower rates of those with primary and higher education levels $(19.51 \%$ and $12.20 \%$, respectively). As many as $53.66 \%$ of the subjects were single, while married people accounted for $32.52 \%$ of the study group, $10.57 \%$ were divorced and $3.25 \%$ were widowed. Residents of rural and urban areas accounted for $55.28 \%$ and $44.72 \%$ of the study group, respectively. As many as $61.21 \%$ of the patients reported welfare benefits as the main source of income. Only $27.59 \%$ of the subjects earned their living owing to paid employment, while $9.44 \%$ of the subjects were unemployed.

The study applied two standardised research tools. COPE Inventory developed by Ch. S. Carver, M. F. Scheier, and J. K. Weintraub, and adapted by Z. Juczyński and N. Ogińska-Bulik, is a tool enabling measurement of 15 coping strategies for stress [24]. Reliability of COPE for the study group, estimated based on Cronbach's $\alpha$ for the specific scales, was in the range from 0.42 to 0.93 .

Disease Perception Questionnaire is a psychometric tool proposed by B. Pawłowska and E. Potembska, and designed to assess self-perceived image of one's condition and attitudes towards the illness. The questionnaire consists of four scales: illness as a threat, weakness, task and benefit [11]. Reliability of the tool was verified taking into account the values of Cronbach's alpha coefficients. In the study group internal compatibility of the tool in the specific scales ranged from 0.85 to 0.93 . Sociodemographic information was acquired using a specially designed survey.

Statistical analyses were computed using SPSS 21 statistics software. Distributions of the relevant parameters were estimated based on KolmogorovSmirnov test. One-way ANOVA for independent samples was applied to examine inter-group differences in the variables whose distributions corresponded to normal distributions. Multiple post-hoc comparisons were conducted using Bonferroni test. Additionally, estimation of effect size was performed using $\eta 2$ statistics for independent samples.

\section{Results}

Coping strategies for stress used by individuals with various mental disorders

The findings showed a statistically significant effect of the variable 'type of mental disorder' for six strategies of coping with stress.

The obtained data suggest that the type of mental disorder differentiates the group for the frequency of seeking instrumental support $F=(4,118)=2.54, p=0.043$, $\eta 2=0.08$. Patients affected by anxiety disorder more frequently seek instrumental support than those addicted to alcohol.

The type of mental disorder also differentiated the group for the frequency of seeking emotional support $F=(4,118)=4.10, p<0.004, \eta 2=0.12$. The patients suffering from anxiety disorders are more likely to look for emotional support, compared to the individuals with alcohol-related problems and those detained due to psychoactive substance-induced psychotic disorders and amnestic syndromes.

Furthermore, there was a statistically significant effect of the variable 'type of mental disorder' in relation to the strategy of positive reinterpretation and growth $F=(4,118)=6.53, p<0.000, \eta 2=0.18$. The individuals addicted to alcohol are significantly less likely to use the strategy of re-framing a problem situation in positive terms compared to those suffering from anxiety disorders or those detained due to psychoactive substance-induced psychotic disorders and amnestic syndromes.

The type of mental disorder also differentiated the study group in terms of the frequency of using the strategy of focus on and venting emotions $F=(4,118)=$ $6.44, p<0.000, \eta 2=0.18$. The patients affected by anxiety disorders are more likely to focus on emotions and on expressing these compared to those detained due to psychoactive substance-induced psychotic disorders and amnestic syndromes or individuals with alcohol addiction.

The findings show that the type of mental disorder differentiates the group for the use of the coping strategy involving substance use, $F=(4,118)=12.76, p<0.000, \eta 2$ $=0.30$. The individuals addicted to alcohol significantly more frequently employ the strategy directed towards the use of alcohol and drugs compared to the patients suffering from anxiety disorders, those detained due to psychoactive substance-induced psychotic disorders and amnestic syndromes, patients with depressive disorders and schizophrenia.

A significant effect of the variable of mental disorder was observed in the case of the coping strategy which involves planning $F=(4,118)=2.50, p=0.046, \eta 2=0.08$. The patients detained due to psychoactive substanceinduced psychotic disorders and amnestic syndromes are more likely to resort to planning than those with 
alcohol addiction. The detailed data related to the coping various mental disorders, are listed in Table 1. strategies for stress, employed by the subjects affected by

Table 1. Coping strategies for stress, used by patients with various types of mental disorders

\begin{tabular}{|c|c|c|c|c|c|c|c|c|c|c|c|c|c|}
\hline \multirow[t]{2}{*}{ Strategy } & \multicolumn{2}{|c|}{$\begin{array}{c}\text { Schizophrenia } \\
1\end{array}$} & \multicolumn{2}{|c|}{$\begin{array}{l}\text { Depressive } \\
\text { disorders } 2\end{array}$} & \multicolumn{2}{|c|}{$\begin{array}{l}\text { Alcohol- } \\
\text { related } \\
\text { disorders } 3\end{array}$} & \multicolumn{2}{|c|}{$\begin{array}{c}\text { Anxiety } \\
\text { disorders } 4\end{array}$} & \multicolumn{2}{|c|}{$\begin{array}{c}\text { Psychoactive } \\
\text { substance- } \\
\text { induced } \\
\text { psychotic } \\
\text { disorders, } \\
\text { detention } 5\end{array}$} & \multirow[t]{2}{*}{$F$} & \multirow[t]{2}{*}{$p$} & \multirow[t]{2}{*}{$\begin{array}{c}\text { Post hoc } \\
\text { Bonferroni }\end{array}$} \\
\hline & $M$ & $S D$ & $M$ & $S D$ & $M$ & $S D$ & $M$ & $S D$ & $M$ & $S D$ & & & \\
\hline$A C$ & 11.41 & 1.95 & 11.40 & 1.67 & 10.40 & 2.24 & 11.29 & 1.65 & 11.60 & 2.55 & 1.47 & 0.216 & \\
\hline UISS & 10.93 & 2.77 & 10.85 & 2.87 & 9.17 & 2.70 & 11.67 & 4.07 & 10.00 & 2.89 & 2.54 & 0.043 & $3-4$ \\
\hline UESS & 10.74 & 3.55 & 10.15 & 3.62 & 8.67 & 2.44 & 12.19 & 4.17 & 9.32 & 2.87 & 4.10 & 0.004 & $3-4,4-5$ \\
\hline$S C A$ & 11.11 & 2.26 & 10.55 & 2.01 & 10.17 & 2.18 & 10.76 & 1.55 & 10.92 & 2.45 & 0.81 & 0.521 & \\
\hline$R C$ & 10.04 & 4.40 & 11.50 & 4.07 & 9.03 & 3.76 & 12.24 & 4.59 & 10.64 & 4.15 & 2.20 & 0.073 & \\
\hline$P R G$ & 10.70 & 2.27 & 10.65 & 2.52 & 9.13 & 1.63 & 12.00 & 2.10 & 11.48 & 2.43 & 6.53 & 0.000 & $3-4,3-5$ \\
\hline$R$ & 10.33 & 2.43 & 10.65 & 2.70 & 9.60 & 2.42 & 9.76 & 1.34 & 10.84 & 2.37 & 1.38 & 0.245 & \\
\hline$A$ & 10.41 & 2.37 & 11.50 & 2.24 & 10.57 & 2.06 & 9.95 & 1.47 & 10.96 & 2.78 & 1.44 & 0.226 & \\
\hline FVE & 11.22 & 2.71 & 11.05 & 2.78 & 9.70 & 1.68 & 12.67 & 1.98 & 9.76 & 2.54 & 6.44 & 0.000 & $3-4,4-5$ \\
\hline$D$ & 8.15 & 3.01 & 7.35 & 2.39 & 8.73 & 2.10 & 9.19 & 2.32 & 7.72 & 2.69 & 1.93 & 0.111 & \\
\hline$M D$ & 9.52 & 2.41 & 9.35 & 2.11 & 8.63 & 2.13 & 10.10 & 2.23 & 9.12 & 2.17 & 1.47 & 0.217 & \\
\hline$B D$ & 9.26 & 2.47 & 8.85 & 2.83 & 8.30 & 2.26 & 9.05 & 2.58 & 7.60 & 2.65 & 1.74 & 0.146 & \\
\hline$S U$ & 5.96 & 3.75 & 5.70 & 2.68 & 11.10 & 2.81 & 7.10 & 2.93 & 6.80 & 3.71 & 12.76 & 0.000 & $\begin{array}{l}1-3,2-3, \\
3-4,3-5\end{array}$ \\
\hline$H$ & 6.93 & 2.73 & 5.85 & 1.95 & 7.53 & 2.56 & 7.52 & 2.42 & 7.80 & 2.52 & 2.15 & 0.078 & \\
\hline$P$ & 11.52 & 2.12 & 11.05 & 2.87 & 10.27 & 2.72 & 10.81 & 2.09 & 12.28 & 2.51 & 2.50 & 0.046 & $3-5$ \\
\hline
\end{tabular}

Active coping (AC), Use of instrumental social support (UISS) Use of emotional social support (UESS) Suppression of competing activities (SCA) Religious coping (RC) Positive reinterpretation and growth (PRG) Restraint (R) Acceptance (A) Focus on and venting of emotions (FVE) Denial (D) Mental disengagement (MD) Behavioural disengagement (BD) Substance use (SU) Humour (PH) Planning (P)

Disease perception in subjects affected by various types of mental disorders

The analyses conducted showed statistically significant effect of the variable of mental disorder and disease perception of the condition as a threat, weakness and task.

The type of mental disorder differentiates the subjects in relation to their perception of their condition as a threat $F=(4,118)=4.19, p=0.003, \eta 2=0.12$. The patients detained due to psychoactive substance-induced psychotic disorders and amnestic syndromes are significantly less likely to see their condition as a threat compared to those affected by depressive disorders and schizophrenia. Type of mental disorder also differentiated the group with regard to the perception of the condition as a weakness $F=$ $(4,118)=8.92, p<0.000, \eta 2=0.23$. The patients suffering from anxiety disorders tend to more frequently see their condition as a weakness, compared to patients suffering from schizophrenia, those with depressive disorders and those detained due to psychoactive substance-induced psychotic disorders and amnestic syndromes. Post hoc multiple comparisons also confirmed that patients with alcohol-related problems more frequently perceive their condition as a weakness, compared to those detained due to psychoactive substance-induced psychotic disorders and amnestic syndromes. 
Type of mental disorder also differentiated the subjects in relation to their perception of their condition as a task $F=(4,118)=3.81, p=0.006, \eta 2=0.21$. The patients affected by anxiety disorders are significantly less likely to see their condition as a task, compared to patients suffering from schizophrenia and those detained due to psychoactive substance-induced psychotic disorders and amnestic syndromes. The detailed data related to illness beliefs in the subjects affected by various mental disorders, are listed in Table 2.

Table 2. Illness beliefs in patients with various mental disorders

\begin{tabular}{|c|c|c|c|c|c|c|c|c|c|c|c|c|c|}
\hline \multirow[t]{2}{*}{$\begin{array}{l}\text { Disease per- } \\
\text { ception }\end{array}$} & \multicolumn{2}{|c|}{$\begin{array}{c}\text { Schizophrenia } \\
1\end{array}$} & \multicolumn{2}{|c|}{$\begin{array}{l}\text { Depressive } \\
\text { disorders } 2\end{array}$} & \multicolumn{2}{|c|}{$\begin{array}{l}\text { Alcohol- } \\
\text { related } \\
\text { disorders } 3\end{array}$} & \multicolumn{2}{|c|}{$\begin{array}{c}\text { Anxiety } \\
\text { disorders } 4\end{array}$} & \multicolumn{2}{|c|}{$\begin{array}{c}\text { Psychoactive } \\
\text { substance- } \\
\text { induced } \\
\text { psychotic } \\
\text { disorders, } \\
\text { detention } 5\end{array}$} & \multirow[t]{2}{*}{$F$} & \multirow[t]{2}{*}{$p$} & \multirow[t]{2}{*}{$\begin{array}{l}\text { Post hoc } \\
\text { Bonferroni }\end{array}$} \\
\hline & $M$ & $S D$ & $M$ & $S D$ & $M$ & $S D$ & $M$ & $S D$ & $M$ & $S D$ & & & \\
\hline $\begin{array}{c}\text { Weak } \\
\text { ness }\end{array}$ & 28.11 & 12.36 & 25.55 & 11.19 & 32.07 & 13.06 & 41.76 & 8.05 & 21.84 & 13.75 & 8.92 & 0.000 & $1-4,2-4$ \\
\hline Threat & 54.44 & 18.77 & 58.40 & 15.97 & 49.60 & 14.79 & 53.62 & 8.35 & 39.88 & 21.82 & 4.19 & 0.003 & $3-5,4-5$ \\
\hline Task & 35.44 & 6.92 & 34.25 & 731 & 30.90 & 10.01 & 28.05 & 4.68 & 35.80 & 10.04 & 3.81 & 0.006 & $1-5,2-5$ \\
\hline Benefit & 31.78 & 13.81 & 31.10 & 9.56 & 30.97 & 13.01 & 35.19 & 8.28 & 24.96 & 13.98 & 2.14 & 0.080 & $1-4,4-5$ \\
\hline
\end{tabular}

\section{Discussion}

The current findings show that patients suffering from anxiety disorders more frequently seek instrumental support than those addicted to alcohol. Furthermore, they are more likely to employ a strategy aiming to seek emotional support, and tend to more often focus on emotions and their expression, compared to those addicted to alcohol and the detained. Compared to all the other groups, the subjects with alcohol addiction most frequently use alcohol and drugs to cope with stressful situations. On the other hand, they are less likely to employ a strategy aiming at positive reinterpretation of a problematic situation than the patients suffering from anxiety disorders or those detained due to psychoactive substance-induced psychotic disorders and amnestic syndromes. Additionally, the latter subjects are significantly more likely to use planning as a coping strategy, compared to the patients with alcohol-related disorders. With reference to the identified inter-group differences, it should be emphasised that the level of neuroticism, which is high in individuals with anxiety disorders, significantly affects the choice of strategies for coping with stress [25]. Matheson and Anisman point out that affective and anxiety disorders are linked with increased levels of "rumination" related to difficult situations, cognitive distraction as well as emotion-focused coping [17]. On the other hand, Pozzi et al. reported that the subjects with diagnosed anxiety disorders were most likely to employ strategies for seeking emotional social support and for avoidance, what is associated with psychopathological symptoms of this condition [15]. Looking for information and help, as a strategy for seeking instrumental support, frequently aims at receiving attention and care of relatives, rather than at solving a problem in challenging situations. In the case of alcoholics, the mechanisms contributing to the addiction include illusions and denials. The mechanism allows to develop a defence system as a result of which, no help is needed from one's social environment [26]. Rather than accumulating emotions, addicts regulate them with the help of substitute activities, i.e. drinking, which functions as a reward [27,28].

Furthermore, the differences in therapies administered to those with anxiety disorders and with addictions may explain the identified disparities in the likelihood of employing the strategy focusing on positive reinterpretation. As a standard, cognitive therapy applied in neuroses is designed to teach patients to change the way of thinking about stressful situations, whereby the intensity of negative affect experienced by them is reduced [29]. Hence, it is not surprising that following therapy patients with anxiety disorders present a change in their use of the strategy aiming at positive reinterpretation of the situation [30, 31]. As for addiction treatment, its initial goal (according to Minnesota model) is to admit that one is powerless over alcohol and to accept one's identity as an alcoholic [32]. This is a key element which makes it possible to introduce the subsequent stages of the therapy, aimed at increasing the patient's self-awareness [33]. In order to change addictive behaviours, it is essential to gain knowledge of one's unconscious desires and defences. Development of self-awareness in alcoholics makes it possible for them to continue the therapy long enough so that a change in emotional regulation mechanisms can take place $[27,28]$. Reinterpretation is not aimed at reframing the situation in positive terms but at reinforcing 
the motivation for change [34,35].

Involuntary commitment into a psychiatric facility ('psychiatric detention') is a precautionary measure applied in the case of individuals who committed an offence while being non-accountable; it is firstly intended to protect the society, and secondly to ensure treatment [36]. Just like prisoners faced with a perspective of long-term confinement, patients must also develop mechanisms enabling reinterpretation of the situation, to make it bearable [37]. In a review article, Maschi, Dennis, Gibson, MacMillan, Sternberg and Hom concluded that cognitive and coping resources function as a protective factor which strengthens inmates against adverse consequences of stress and trauma [38]. On the other hand, people with addictions can voluntarily initiate and continue psychiatric treatment, which also to a lesser degree enforces the use of cognitive mechanisms for the reinterpretation of the existing situation, in order to adapt to the confinement [39].

In the context of illness beliefs, the present findings show that the patients with anxiety disorders are significantly more likely to treat illness as a weakness, compared to the patients with depressive disorders, patients suffering from schizophrenia or the detained. On the other hand, they treat the illness as a task less frequently than patients suffering from schizophrenia or the detained. Illness is a greater threat for the subjects suffering from depressive disorders or schizophrenia than for the detained. Anxiety disorders are characterised by high-intensity anxiety, and a study by Pawłowska, Międlar, Międlar and Dziurzyńska demonstrated a significant relationship between intensity of anxiety and the likelihood of the attitude towards the condition, manifested by a tendency to underrate and dismiss its symptoms [12]. Concealment and denial of the disease, if it is treated as a weakness, may result from activation of defence mechanisms such as rationalisation and repression [16]. These allow to reduce the sense of threat in the case of an illness linked with social stigmatisation, and to minimise focus on suffering and the resulting anxiety [18]. Detained subjects' task-based approach to illness and their willingness to combat the disease may be determined by their motivation to regain freedom. Since involuntary commitment is frequently caused by temporary non-accountability at the time an offence is committed, those in confinement may feel capable of controlling their behaviour, failing to recognise any signs of psychopathology. On the other hand, because of its aetiology, those affected by anxiety disorders are more likely to seek strength outside rather than inside when dealing with difficult situations [15]. Of key importance in a perception of illness as a threat are cognitive responses to stress displayed by depressed subjects.
Kessler established that, compared to healthy individuals, those affected by depression see life events as far more threatening and challenging [40]. As proposed by Lazarus, cognitive interpretation of an event as a stressful fact depends on the meaning attributed to it by an individual, and those affected by depression use dysfunctional cognitive schemas [41,42]. Depression adversely affects their quality of life and effectiveness at work, ruins social relations, and most importantly constitutes a threat to their life and well-being [5]. Similarly, it is difficult to attribute any positive values to schizophrenia due to the irregular course of the condition and the social stigma $[7,18]$. The illness imposes limitations on schizophrenics in all dimensions of their lives. Different situation is experienced by those detained due to psychoactive substance-induced psychotic disorders and amnestic syndromes. The condition is attributed with a different meaning because one's life is ruined as a result of the committed offence, and confinement in hospital is a better alternative than imprisonment.

\section{Conclusions}

Based on the reported findings, it is possible to draw a conclusion that the type of mental disorder differentiates the subjects with respect to the frequency with which they use the strategies aimed at seeking instrumental and emotional support, planning, positive reinterpretation, focus on emotions and use of alcohol. Moreover, there are significant differences in the perception of illness as a task, weakness and threat in patients with depressive disorders, anxiety disorders, schizophrenia, alcohol addiction and those detained due to amnestic disorders. The results show that psychopathological symptoms of a given disorder are of importance in the context of the strategies used for coping with stress and the patients' approach to their condition.

It should be pointed out that a significant limitation of the study results from the small size of the groups. Additionally, male subjects accounted for $72 \%$ of the study group, therefore, in further research it is necessary to recruit the same numbers of males and females affected by the specific mental disorders. The findings lead to questions about mediating effect of sex in the relevant phenomena. They can also provide arguments in the discussion related to factors which are of importance from the viewpoint of therapeutic programs designed for specific mental disorders.

The differences between the groups, identified in the study, carry practical implications particularly important in designing interventions to enable adjustment to the existing mental condition, its acceptance and perception in the context of a valuable life experience. This is important because in the case of chronic disorders, 
the recurring experience of relapses and irrational expectation of complete recovery may lead to exhaustion and to intensified psychopathological symptoms. Activities addressed to psychiatric patients should aim to encourage the use of different strategies for coping with challenging situations than those which are determined by the aetiology and symptoms of the disorder. Review of literature related to effectiveness of psychotherapeutic programs suggests it is important to develop selfregulation mechanism based on interpretation of one's condition in the context of involvement in the therapy $[10,30]$.

\section{Conflict of interest}

The authors have declared no conflict of interest.

\section{References:}

1. Niebrój LT. Defining health/illness: Societal and/or clinical medicine? Journal of Physiology and Pharmacology. 2006; 57 (4): 251-262.

2. Petrie K J, MacKrill K, Derksen C, Dalbeth N. An illness by any other name: The effect of renaming gout on illness and treatment perceptions. Health Psychology. 2018; 37(1), 37-41.

3. Petrie KJ, Broadbent E, Kydd R. Illness perceptions in mental health: Issues and potential applications. Journal Mental Health. 2008;17(6):559-564.

4. Chemperek E, Patyrak J, Wieczorski M. Analiza postaw pacjentów wobec choroby. Zdrowie Publiczne. 2008; 118 (3): 259-263.

5. Fortune G, Barrowclough C, Lobban F. Illness representations in depression. British Journal Clinical Psychology. 2004 43(4):347-364.

6. Hagger M S, Orbell S. A Meta-Analytic Review of the CommonSense Model of Illness Representations. Psychology and Health. 2003; 18(2):141-184.

7. Lobban F, Barrowclough C, Jones S. Assessing cognitive representations of mental health problems. I. The illness perception questionnaire for schizophrenia. British Journal Clinical Psychology. 2005; 44:147-162.

8. Osińska K. Twórcza obecność chorych. PAX; Warszawa: 1980.

9. Hussain S, Imran N, Hotiana UA, Mazhar N, Asif A. Illness perceptions in patients of schizophrenia: A preliminary investigation from Lahore, Pakistan. Pakistan Journal Medical Science. 2017; 33(4):1-6.

10. Williams K, Steer H. Illness perceptions: are beliefs about mental health problems associated with self-perceptions of engagement in people with psychosis? Behavioral Cognitive Psychotherapy. 2011; 39(2):151-163.

11. Pawłowska B, Potembska E, Pić J, Pić N, Pić K. Właściwości psychometryczne Kwestionariusza do badania Obrazu własnej Choroby Current Problem in Psychiatry. 2016; 17(2), 83-89.

12. Pawłowska B, Międlar K, Biały-Międlar K, Dziurzyńska E. Niepokój a postawy wobec choroby u pacjentek z guzami jajnika i mięśniakami macicy. Current Problem

in Psychiatry. 2012; 13 (3): 209-215

13. Heszen I. Psychologia stresu. Wydawnictwo Naukowe PWN; Warszawa, 2013.

14. Lysaker PH, Bryson OJ, Marks K, Qreig TC, Bell MD. Coping Style in Schizophrenia: Associations With Neurocognitive Deficits and Personality. Schizophrenia Bulletin. 2004; 30(1): 113-121.
15. Pozzi G, Frustaci A, Tedeschi D, Solaroli,S. Grandinetti P, Di Nicola $\mathrm{M}$, et al. Coping strategies in a sample of anxiety patients: factorial analysis and associations with psychopathology. Brain and Behavior, 2015; 5(8), e00351

16. Czubalski K. Wpływ choroby na stan psychiczny i zachowanie człowieka chorego. Sztuka Leczenia. 1995; 1(3); 53-59.

17. Matheson K, Anisman H. Systems of Coping Associated with Dysphoria, Anxiety and Depressive Illness: A Multivariate Profile Perspective. Stress. 2003; 6 (3), 223-234.

18. Dinos S, Stevens S, Serfaty M, Weich S, King M. Stigma: the feelings and experiences of 46 people with mental illness. Qualitative study. British Journal Psychiatry. 2004; 184:176181.

19. American Psychiatric Association (APA). Diagnostic and Statistical Manual of Mental Disorders. 5th ed Washington, DC: APA; 2013.

20. Telles-Correia D, Saraiva S, Gonçalves J. Mental Disorder-The Need for an Accurate Definition. Frontiers in Psychiatry. 2018; 12, 9:64.

21. Zhang M, Hong L, Zhang T, Lin Y, Zheng S, Zhou X, et al. Illness perceptions and stress: mediators between disease severity and psychological well-being and quality of life among patients with Crohn's disease. Patient Prefer Adherence. 2016; 10: 2387-2396.

22. Pużyński S. Choroba psychiczna-problem $\mathrm{z}$ definicją oraz miejscem $\mathrm{w}$ diagnostyce regulacjach prawnych. Psychiatria Polska. 2007; 41 (3), 299-308.

23. Pyrcak M. Orzekanie oraz wykonywanie detencji psychiatrycznej (art. 94 k.k.) w praktyce sądów rejonowych. Sprawozdanie z przeprowadzonych badań. Czasopismo Prawa Karnego i Nauk Penalnych. 2011; XV, 1, 99-136.

24. Juczyński Z. Ogińska-Bulik N.(2009). Narzędzia pomiaru stresu i radzenia sobie ze stresem. Warszawa: PTP.

25. Vollrath M, Torgersen S, Alnæs R. Neuroticism, coping and change in MCMI-II clinical syndromes: test of a mediator model. Scandinadian Journal of Psychology. 1998; 39, 15-24.

26. Mellibruda J, Sobolewska-Mellibruda Z. Integracyjna psychoterapia uzależnień Teoria i praktyka. Warszawa: Instytut psychologii Zdrowia PTP; 2011.

27. Mellibruda J. Psycho-bio-społeczna koncepcja uzależnienia od alkoholu. Alkoholizm i Narkomania. 1997; 3, 28, 277-306.

28. Woronowicz B. Uzależnienia. Geneza, terapia, powrót do zdrowia. Warszawa: Parpamedia; 2009.

29. Wells A. Terapia poznawcza zaburzeń lękowych : praktyczny podręcznik i przewodnik po teorii. Kraków : Wydawnictwo Uniwersytetu Jagiellońskiego; 2010

30. Ociskova M, Prasko J, Kamaradova D, Grambal A, Kasalova P. Sigmundova Z. et al. Coping strategies, hope, and treatment efficacy in pharmacoresistant inpatients with neurotic spectrum disorders. Neuropsychiatric Disease and Treatment. 2015; 11, 1191-1201.

31. Wesner AC, Gomes JB, Detzel T, Blaya C, Manfro GG, Heldt E. Effect of cognitive-behavioral group therapy for panic disorder in changing coping strategies. Comprehensive Psychiatry. 2013; 55 (1), 87-92.

32. Bukowski S, Bukowska B, IInick SOcena efektywności ambulatoryjnej terapii alkoholików wzorowanej na modelu Minnesota. Alkoholizm i Narkomania. 1999; 2, 35, 237-245.

33. Connors GJ, DiClemente CC, Marden Velasquez M, Donovan DM: Etapy zmiany w terapii uzależnień. Wybór i planowanie interwencji. Wydawnictwo Uniwersytetu Jagielońskiego, Kraków; 2015.

34. Beck AT, Wright FD, Newman C F, Liese BS. (2007). Terapia poznawcza uzależnień. Kraków: Wydawnictwo Uniwersytetu Jagiellońskiego; 2007. 
35. Miller WM. Wzmacnianie motywacji do zmiany w terapiach nadużywania substancji: PARPA; 2009.

36. Kwieciński A. Lecznicze środki zabezpieczające $\mathrm{w}$ polskim prawie karnym i praktyka ich stosowania. Wrocław: Kolonia Limited; 2009.

37. Maschi T, Viola D, Koskinen L. Trauma, Stress, and Coping Among Older Adults in Prison: Towards a Human Rights and Intergenerational Family Justice Action Agenda. Traumatology American Psychological Association. 2015; 21, 3, 188 -200.

38. Maschi T, Morgen K, Zgoba K, Courtney D, Ristow, J. Trauma, stressful life events, and posttraumatic stress symptoms: Do subjective experiences matter? Gerontologist. 2011; 51(5), 675686.

39. Miller P. Terapia uzależnień - metody oparte na dowodach naukowych. Warszawa: Wydawnictwo Uniwersytetu Warszawskiego; 2013

40. Kessler RC. The effects of stressful life events on depression. Annual Review Psychology, 1997; 48, 191-214.

41. Smith CA, Lazarus RS. Appraisal components, core relational themes, and the emotions. Cognition and Emotion. 1993; 7(3/4), 233-269.
42. Smith CA, Haynes K, Lazarus RS, Pope LK. In search of the 'hot' cognitions: attributions, appraisals, and their relation to emotion. Journal of Personality and Social Psychology. 1993; 65(5), 916-929.

\section{Corresponding author}

Wioletta Ozga

Institute of Psychology, The John Paul

II Catholic University of Lublin

Al. Racławickie 14, 20-950 Lublin,

phone number: 815376084

e-mail:w.k.ozga@gmail.com

Otrzymano: 29.05.2019

Zrecenzowano: 30.06.2019

Przyjęto do druku: 30.06.2019 